\title{
PECULIARITIES OF CONSTRUCTIVE THINKING FORMATION
}

\section{L.V. Berezova, Senior Lecturer \\ National University of Life and Environmental Sciences of Ukraine}

Tasks, questions and practical tasks is an effective didactic way, which makes active creative activity of the person. The constructive thinking carried out at the decision of creative tasks is considered.

The creative thinking is search and discovering of something new. For creative work, it is necessary to have ability independently and critically to think, make through nature of subjects and phenomena, to be inquisitive, that appreciably provides productivity of mental activity.

Creative thinking is generally considered to be involved with the creation or generation of ideas, processes, experiences or objects; critical thinking is concerned with their evaluation.

Creative thinking involves creating something new or original. It involves the skills of flexibility, originality, fluency, elaboration, brainstorming, modification, imagery, associative thinking, attribute listing, metaphorical thinking, and forced relationships. The aim of creative thinking is to stimulate curiosity and promote divergence.

Necessity every day to solve the contradiction of vital circumstances (tasks) has generated requirement, and necessity of operating by knowledge results in development of intellection. The person has got used to this, that the concept "task" does not contact daily life, and it is carried to categories of pedagogic, science. Though any knowledge, even what is accepted by us as unconditional true, are the results of persevering human searches, which have arisen and solved as new difficult tasks.
The task, as a rule, is the problem set or formulated independently which demands from the subject of the certain actions at finding of the answer to that or other question, which contains in a condition of task. It can be a task on mathematics, and a task, which emerges in conditions of game, an administrative task, etc. Psychological task emerges (is formulated) for the subject in the case when he does not know how to reply, how to orient in the given situation, he needs to search for the answer, especially to organize the activity.

Works of these scientists and others, for exampleL. Gurova, G. Kostyuk, T. Kudryavtsev, E. Mileryan give grounds to consider the activity directed on the decision of new tasks, as the important preparation for creativity, as the form of creative activity [1, 2].

The creative task, as marks V. Molyako, is completely new or unfamiliar for the subject, or at least, contains significant newness, which defines the intellectual efforts, special search, finding of a new method of the decision [3].

Tasks, the questions and practical tasks are effective didactic means, which make active creative activity of subjects, and especially if they are problem, they have contradictions in their contents. The overlap between creative and constructive thinking becomes more and more obvious. We see creativity as a way to be 'constructive'. Creativity is most effective when 
embedded in constructive thinking. It is quite possible to be constructive without being exceptionally creative. This can be done with designs that put together known elements in standard ways. It is also done by yellow hat focus on positive aspects and then seeking to develop these.

Edward de Bono notes that the constructive thinking that delivers values. Creative thinking may design new values and may suggest new ways of delivering values but it is constructive thinking that makes things happen. There is not as much hype and mystique around constructive thinking. That may be a good thing. It is also a good thing that creative people put more emphasis on constructive thinking [4].

Constructive thinkers develop the habit of approaching challenges or questions from solution-oriented perspectives. Constructive thinking requires more of a shift in personal attitude and philosophy than it does adoption of techniques or strategies, and although logic would suggest that, everyone should be constructive. Incredibly, many societies and cultures cultivate destructive and confrontational modes of thinking and acting to the point where we tend to view them as being normal and acceptable. Of course, people do not think they are being deliberately destructive or confrontational, but consider how our governments, courts, workplaces and even home environments often operate.

The confrontational approach is a tenuous strategy because it tends to make proponents of a particular point of view isolationist and thus denies the opportunity and inclination to seek out alternatives or opposing points of view.

You have probably known people who seem to move naturally in constructive directions when confronted by a question, problem, or issue. They seem to instinctively seek positive outcomes and eagerly involve others in helping to reach solutions. You have probably also known people who seem more inclined to view challenges as annoyances. These people often begin their thinking process with a litany of negatives: "I can't solve this..." or "I've got enough to do already..." or "I know what I'd like to do but these other people just don't seem to get the point..."

Becoming a consistent constructive thinker comes first from forming the appropriate mental mindset and then by disciplining yourself to practice being constructive. In addition, do not overlook the fact that being constructive almost automatically helps us to be more likable-an important consideration in the careers.

Rather frequently constructive activity begins from finding of the contradiction. Not everyone is capable to notice the contradiction, but only the one who is ready to these. Such people have necessary skill and knowledge of that sphere in which there are contradictions, they have advanced abilities - the generated conforming readiness. Ingenious people who are able to notice the contradiction in the environmental world, become inventors of ideas in this or that sphere of creativity: social, pedagogical, scientific, technical, art, etc.

V. Molyako points the paradigm of strategy organization of creative processes, concrete processes of creative activity provides such purposeful actions, which resolve:

- actualization an available knowledge, are necessary for understanding of a new task; - direct search of the project of the decision; - invent " current technologies" the decision; - apply these technologies in conditions of a new task;

- estimate the reached decision [5].

A strategy is taken to mean a rather complex psychological formation comprising preparatory, planning and realization acts, which are related to the fulfilment of the individual's, potentialities in the concrete situation of creative activity [3].

Five major strategies in design engineers' intellective activity have been identified: 1) a search for analogues, 2) combinatorial actions, 3) redesigning actions, 4) universal strategy, 5) random substitutions. Each of these is primarily geared to creating a particular engineering structure with particular functions, to structur- 
al-functional transformation of engineering devices, which is, in fact, related to the essence of design engineering [3].

If to look on system CARUS (1) a search for analogues, 2) combinatorial actions, 3) redesigning actions, 4) universal strategy, 5) random substitutions) developed by V. Molyako it is necessary to mean, that the constructive intellection is connected first of all to the decision of a different sort of constructive tasks which provide transformation of the information, actual for their decision, according to conditions of a task with the purpose of building the certain frame with the certain functions [3].

The constructive thinking is directed on display, studying, research of a situation, a state of things, which are subject to comprehension - in general actual information structure based on structurally functional analysis of elements of this system in their interaction with the purpose of its transformation according to external and internal conditions [6].

Process of formation of constructive thinking can be submitted in four levels: kindergarten, school, high school and professional level. The fourth level is characterized by high professionalism, skill, skill independently to predict, build and considerably to solve tasks. To the enterprises, which want to be competitive qualified employees are necessary.

Process of formation of professional constructive thinking is continuous during all vital activity.

Creativity should become norm of professional work and preparation to it, i.e. in a final variant we speak that each expert should be the creative expert. Certainly, a level of creative activity always there will be different, as in each concrete case creative opportunities of each worker determined by its abilities, endowments, talent [5].

In the conclusion we shall note, that any creative activity demands a high level formed professional constructive thinking based on strong stereotypes of activity. Students who have advanced level of the constructive thinking keep up to date, look in the future, show readiness for correctly estimation and using of experience, processed it creatively and enriched with own independent finds.

\section{Referenses}

1. Kudryavtsev, T.V. (1975). Psychology of technical thinking. Moscow: Pedagogica, 304, (in Russia).

2. Molyako V.A. (1983). Psychology of solution of pupils of creative tasks. Kiev: Radianska Shkola, 94, (sn Ukraine).

3. Molyako V.A. (1983). Psychology of design activity. Moscow: Mashinostroyeniye, 134, (in Russia).

4. Edward de Bono (2005). Non-standard thinking. Manual for self-tuition. Moscow: Poppuri, 272, (in Russia).

5. Molyako V.O. (2004). Psychology of creativity - new paradigm researching of the constructive activity of a man. Practical psychology and social work, 8, 1-4.

6. Tretyak T.M. (2006). Constructive thinking in the structure of creative potential of a personality. Practical psychology and social work, №1, 18-20.

\section{АНОТАЦІЯ}

Березова Л.В. Особливості формування конструктивного мислення // Біоресурси $i$ природокористування. - 2016. - 8, №3-4. C.105-108.

Завдання, питання і практичні завдання - ефективний дидактичний шлях, який робить активну твориу діяльність людини. Розалядається конструктивне мислення, яке відбувається при розв'язуванні творчих задач.

\section{АННОТАЦИЯ}

Березовая Л. В. Особенности формирования конструктивного мысшления //Биоресурсы и природопальзование. - 2016. - 8, №3-4. - С. 105-108.

Задачи, вопросы и практические задачи эффективный дидактический путь, который делает активную творческую деятельность человека. Рассматривается конструктивное мылиление, которое происходит при решении творческих задач. 